\title{
Editorial
}

Digestion

\section{Gastroesophageal Reflux and Atypical Symptoms: The Role of Impedance-pH Monitoring}

\author{
Fernando Fornari Daniel Sifrim \\ Center for Gastroenterological Research, Catholic University of Leuven, Leuven, Belgium
}

Gastroesophageal reflux disease (GERD) is a condition which develops when reflux of stomach contents causes troublesome symptoms and/or complications [1]. GERD manifestations include esophageal and extraesophageal syndromes, with the latter also known as GERD with atypical symptoms. Associations between this category of symptoms and GERD have been established for chronic cough, asthma, chronic laryngitis and dental erosions. The diagnostic approach often used to identify these associations include ambulatory esophageal $\mathrm{pH}$ monitoring, laryngoscopy, and empiric therapy with proton pump inhibitors (PPIs) [2-5]. However, the yield of these techniques to identify GERD as a potential cause of atypical symptoms remains controversial [6-8]. For example, a recent meta-analysis concluded that proximal $\mathrm{pH}$ monitoring gives accurate and consistent information about GERD in patients with laryngopharyngeal reflux [9]. In contrast, a well-designed study with combined dual esophageal $\mathrm{pH}$ and distal Bilitec monitoring failed to support the routine application of proximal $\mathrm{pH}$ monitoring in patients with atypical GERD symptoms [10].

Esophageal impedance-pH monitoring is now considered the most sensitive tool for characterization of GERD. This technique is able to detect not only acid reflux but also weakly acidic episodes either in the esophagus or pharynx $[11,12]$. Several studies have assessed the diagnostic yield of impedance-pH monitoring in the evalua-

\section{KARGER \\ Fax +41613061234 \\ E-Mail karger@karger.ch}

www.karger.com
(C) 2007 S. Karger AG, Basel

0012-2823/07/0764-0221\$23.50/0

Accessible online at:

www.karger.com/dig tion of patients with GERD symptoms, including typical symptoms in patients off PPIs, chronic cough and symptoms refractory to PPIs [13-15]. However, few studies have formerly assessed the benefit of impedance-pH monitoring in patients with laryngeal symptoms.

Chronic cough related to GERD has been generally attributed to acid reflux. However, acid suppression therapy is not as good as for heartburn. Interestingly, cough improvement with antireflux surgery has been repeatedly reported, suggesting a possible involvement of other gastric contents in the triggering of cough. Recent studies investigated the association between weakly acidic reflux and cough using $24 \mathrm{~h}$ ambulatory pressureimpedance-pH monitoring. Manometry and symptom association probability analysis were used for precise recognition of reflux-related cough. These studies allowed the identification of a subgroup of patients in which chronic cough was clearly associated with weakly acidic reflux $[14,16]$. Furthermore, impedance-pH manometry identified patients with reflux-related cough that would have been disregarded using the standard diagnostic criteria for acid reflux.

Laryngeal symptoms possibly related with GERD have been assessed with impedance-pH monitoring $[17,18]$. These studies have shown that weakly acidic gaseous reflux might be more frequent among patients with refluxattributed laryngitis than in controls. In addition, patients with globus sensation refractory to PPIs seem to
Fernando Fornari, MD, $\mathrm{PhD}$

KULeuven, Gasthuisberg O\&N1, Bus 701, Labo. Gastro-intestinale Peptiden Herestraat 49

BE-3000 Leuven (Belgium)

E-Mail Fernando.Fornari@med.kuleuven.be 
have higher frequency of proximal reflux, with weakly acidic reflux approaching significance in predicting globus. Nevertheless, a clear association between laryngopharyngeal reflux and laryngeal symptoms, seen at impedance-pH monitoring, has not yet been established.

In this issue, Bajbouj et al. describe the diagnostic yield of impedance-pH monitoring in patients with atypical symptoms potentially related with GERD [19]. The authors compared the yield of impedance-pH monitoring with impedance only, distal or proximal $\mathrm{pH}$ only and endoscopy in patients with atypical GERD symptoms, including chronic cough, hoarseness or globus sensation. Impedance-pH monitoring showed the highest diagnostic yield in the detection of GERD compared to other techniques. The authors claim that impedance-pH monitoring increases the diagnostic yield for objective detection of atypical manifestations of GERD. Patients were selected based on report of atypical symptoms, but un- fortunately few of them registered symptoms during impedance-pH monitoring. Additionally, proximal impedance and $\mathrm{pH}$ sensors were kept in a permanent position, irrespective of the location of the upper esophageal sphincter and hypopharynx. Such approach limits the assessment of atypical symptoms possibly associated with GERD reaching the proximal esophagus or the pharynx.

In conclusion, based on the study of Bajbouj et al., it seems correct to claim that impedance-pH monitoring is superior to other techniques in the detection of gastroesophageal reflux. It is also accepted in other studies that impedance- $\mathrm{pH}$ monitoring combined with objective methods for detection of atypical symptoms improves the capability of patients' selection. However, the affirmation that impedance-pH monitoring per se increases the diagnostic yield for objective detection of atypical GERD symptoms still deserves further investigation.

\section{References}

1 Vakil N, van Zanten SV, Kahrilas P, Dent J, Jones R: The Montreal definition and classification of gastroesophageal reflux disease: a global evidence-based consensus. Am J Gastroenterol 2006;101:1900-1920.

2 Belafsky PC, Postma GN, Koufman JA: The validity and reliability of the reflux finding score (RFS). Laryngoscope 2001;111:13131317.

3 Hicks DM, Ours TM, Abelson TI, Vaezi MF, Richter JE: The prevalence of hypopharynx findings associated with gastroesophageal reflux in normal volunteers. J Voice 2002;16: 564-579.

4 Numans ME, Lau J, de Wit NJ, Bonis PA: Short-term treatment with proton-pump inhibitors as a test for gastroesophageal reflux disease: a meta-analysis of diagnostic test characteristics. Ann Intern Med 2004;140: 518-527.

5 Oelschlager BK, Eubanks TR, Maronian N, Hillel A, Oleynikov D, Pope CE, Pellegrini $\mathrm{CA}$ : Laryngoscopy and pharyngeal $\mathrm{pH}$ are complementary in the diagnosis of gastroesophageal-laryngeal reflux. J Gastrointest Surg 2002;6:189-194.

6 DeVault K: A BALANCING VIEW: Empiric PPI therapy remains the champ, but not by a knock out! Am J Gastroenterol 2006;101:10 11.

7 Hirano I, Richter JE: ACG practice guidelines: esophageal reflux testing. Am J Gastroenterol 2007;102:668-685.
8 Vaezi MF, Hicks DM, Abelson TI, Richter JE: Laryngeal signs and symptoms and gastroesophageal reflux disease (GERD): a critical assessment of cause and effect association. Clin Gastroenterol Hepatol 2003; 1:333-344. 9 Merati AL, Lim HJ, Ulualp SO, Toohill RJ: Meta-analysis of upper probe measurements in normal subjects and patients with laryngopharyngeal reflux. Ann Otol Rhinol Laryngol 2005; 114:177-182.

10 Cool M, Poelmans J, Feenstra L, Tack J: Characteristics and clinical relevance of proximal esophageal $\mathrm{pH}$ monitoring. Am J Gastroenterol 2004;99:2317-2323.

11 Aslam M, Bajaj S, Easterling C, Kawamura O, Rittmann T, Hofmann C, Liu J, Shaker R: Performance and optimal technique for pharyngeal impedance recording: A simulated pharyngeal reflux study. Am J Gastroenterol 2007;102:33-39.

12 Sifrim D, Castell D, Dent J, Kahrilas PJ: Gastro-oesophageal reflux monitoring: review and consensus report on detection and definitions of acid, non-acid, and gas reflux. Gut 2004;53:1024-1031.

13 Bredenoord AJ, Weusten BL, Timmer R, Conchillo JM, Smout AJ: Addition of esophageal impedance monitoring to $\mathrm{pH}$ monitoring increases the yield of symptom association analysis in patients off PPI therapy. Am J Gastroenterol 2006;101:453-459.
14 Sifrim D, Dupont L, Blondeau K, Zhang X, Tack J, Janssens J: Weakly acidic reflux in patients with chronic unexplained cough during 24 hour pressure, $\mathrm{pH}$, and impedance monitoring. Gut 2005;54:449-454.

15 Zerbib F, Roman S, Ropert A, des Varannes SB, Pouderoux P, Chaput U, Mion F, Verin E, Galmiche JP, Sifrim D: Esophageal pH-impedance monitoring and symptom analysis in GERD: a study in patients off and on therapy. Am J Gastroenterol 2006;101:19561963.

16 Blondeau K, Dupont LJ, Mertens V, Tack J, Sifrim D: Improved diagnosis of gastro-oesophageal reflux in patients with unexplained chronic cough. Aliment Pharmacol Ther 2007;25:723-732.

17 Anandasabapathy S, Jaffin BW: Multichannel intraluminal impedance in the evaluation of patients with persistent globus on proton pump inhibitor therapy. Ann Otol Rhinol Laryngol 2006;115:563-570.

18 Kawamura O, Aslam M, Rittmann T, Hofmann C, Shaker R: Physical and $\mathrm{pH}$ properties of gastroesophagopharyngeal refluxate: a 24-hour simultaneous ambulatory impedance and $\mathrm{pH}$ monitoring study. Am J Gastroenterol 2004;99:1000-1010.

19 Bajbouj M, Becker V, Neuber M, Schmid RM, Meining A: Combined pH-metry/impedance monitoring increases the diagnostic yield in patients with atypical gastroesophageal reflux symptoms. Digestion 2007;76: $223-228$. 